\title{
Adoption of a judgement and exercising control of its performance by a court in administrative proceedings
}

\author{
Evgenii Nikolaevich Kuliushin ${ }^{1}$ \\ Ural State Law University, Department of Civil Procedure, Ekaterinburg, Russia
}

\begin{abstract}
The article examines the essence and content of the powers of the court of first instance to make a judgement and control its implementation in order to improve the effectiveness of judicial protection of violated rights of citizens and organisations against illegal acts of public law bodies, the correctness and timeliness of consideration and resolution of cases in public law disputes, prevention of violations in the area of public law relations, the possibility of reducing the burden on courts of first instance in various categories of public law disputes. The key focus is on the peculiarities of exercising by a court of powers to make court judgements and exercising control of their execution in public law disputes on the basis of historical-legal, comparative-legal and formal-legal methods of researching similar powers of courts in countries of the civil law system (France, Germany) and countries representing the common law system (England, USA), comparing the contents of the powers of the court in administrative proceedings in accordance with the Code of Administrative Procedure of the Russian Federation and the powers of the court in civil and arbitration proceedings. The use of historical-legal, comparative-legal and formal-legal methods for researching the content of powers to adopt a court judgement and exercise control over its execution made it possible to formulate conclusions regarding the scope of procedural actions of the court of first instance in administrative proceedings, the possibilities of improving the model for exercising judicial control over acts in public-legal authorities, correctness and timeliness of execution of court judgements taken against public law authorities in order to ensure that the weak side in administrative proceedings can be protected. The novelty of the work lies in the proof that in order to increase the effectiveness of the protection of the violated rights of individuals against unlawful acts of public authorities, it is necessary to improve the mechanism for the exercise by the court of powers to make a judgement and exercise control over implementing it.
\end{abstract}

Keywords: administrative proceedings, court of first instance, astreinte, court decisions, control over the execution of court decisions

\section{Introduction}

${ }^{1}$ Corresponding author: e.n.kulyushin@usla.ru 
Improving the functioning of the procedural activities of courts to resolve cases in public law disputes is a fundamental activity for increasing the efficiency of protecting the violated rights of citizens and organisations against unlawful acts of public authorities, preventing the emergence of new public law disputes in the future [1].

The violated rights of citizens and organisations are protected through the powers vested in the court, among which the powers of the court to make a court judgement and exercise control its execution should be highlighted [2]. Subjective public law is considered protected if a timely adjudication and its subsequent execution are carried out [3]. With the adoption in 2015 of the Code of Administrative Procedure of the Russian Federation, the resolution of cases in public law disputes was removed from the regulation of the Civil Procedure Code of the Russian Federation. In 2020, the total number of cases considered by courts of general jurisdiction in public law disputes exceeded 6 million. [4]. Therefore, it is essential to understand the forms and limits of exercising by the court of the powers to make a court judgement and exercise control of its execution, the necessity and sufficiency of their implementation by the court in order to ensure that the violated rights of citizens and organisations against unlawful acts of public law bodies can be protected [5]. To achieve this goal, it is necessary to understand the key provisions of the foreign doctrine of administrative proceedings (France, Germany, England, USA), as well as the provisions of the domestic procedural doctrine on the content of the court's powers. The most widespread cases in judicial practice are cases on challenging regulatory documents and cases on challenging non-regulatory documents [6].

Taking into account provisions of the foreign and domestic doctrine, legislation and judicial practice on public law disputes, the following issues are subject to consideration: 1) the need to expand the scope of powers of the court of first instance to control the adopted acts of public law bodies in relation to citizens and organisations; 2) the need to expand the scope of judicial control by the court over the correct and timely execution of court judgements made against public law bodies.

\section{Methods}

When studying the contents of the court's powers to make a judgement and exercise control of its execution in public law disputes, historical legal, comparative legal methods were used, a formal legal analysis of the texts of research articles by foreign authors, such as Capitant, Winkler, Heuen, Brinktrine, Gebhardt [2, 3, 7-9].

The use of historical-legal, comparative-legal and formal-legal methods for researching the contents of powers to make a court judgement and exercise control over its execution made it possible to formulate conclusions regarding the scope of procedural actions of the court of first instance in administrative proceedings, the possibilities of improving the model for exercising judicial control over acts in public-legal authorities, correctness and timeliness of execution of court judgements made against public law authorities in order to ensure that the weak side in administrative proceedings is protected.

\section{Results and discussion}

The study showed that in the works of foreign authors, a detailed research into the procedural legal status of the court of first instance in public law disputes at the present stage, the content and mechanism of the exercise of powers by the court in public law disputes had been obtained. An analysis of them made it possible to identify the features of the contents of the court's powers to make a court judgement and exercise control over its 
execution, to determine the key activities for improving the mechanism for their implementation in the administrative proceedings of the Russian Federation.

\subsection{Features of the powers of the court of first instance in public law disputes}

The essence of the court's procedural actions in public law disputes is manifested in its powers in cases of challenging regulatory and non-regulatory documents (hereinafter referred to as acts of public law bodies).

Concerning the issue of the exercise by the court of powers to make court judgements in administrative proceedings, the domestic and foreign legal reference sources formulate approaches regarding the scope of their implementation by the court in relation to acts of public law bodies:

1) on the impossibility of the court's exercising its powers to verify the appropriateness of the adoption of acts by public authorities; the powers of the court are limited only to questions of legality and validity of acts of public authorities, since the court must respect the reasonable interpretation of laws by public authorities [10].

2) on the need to check the appropriateness of acts of public authorities in administrative proceedings [7].

The expediency of acts of public authorities means that the results of acts adopted by public authorities correspond to the goals provided for in the relevant provisions of law in the settlement of a specific life case [11]. The expediency of the adoption of acts by public authorities ensures the exact balance of private and public interests [12]. The courts of France, Germany, England and the United States, when considering public law disputes, verify the compliance of the act of the public authority with the purpose provided for by law taking into account the correct application of the rules of substantive law and the rules of procedural law [8]. The court examines the margin of appreciation of the competent authority in relation to individuals and the objective need for an adequate measure to be taken to achieve the goal stipulated in the law [9]. Consequently, the court ensures control over the appropriateness of the adopted acts by public authorities within the framework of legality and does not allow the manifestation of departmental interest when they are adopted by public authorities.

\subsection{The content of the powers of the court to make and control judgements in cases of challenging regulatory documents}

Features of the powers of the court when considering cases on challenging regulatory documents include: 1) identification of insufficient legal regulation of public legal relations; 2) the obligation of a public authority to adopt a new regulatory document instead of the invalidated regulatory document (clause 4 of article 216 of the Administrative Court Procedure Code of the Russian Federation); 3) an indication in the reasoning part of the court judgement on the factual circumstances of the recognition of the normative act as invalid, since the factual circumstances established by the court have prejudicial significance for an indefinite circle of persons [13].

In order to improve the model of the procedural activity of the court, the content of its powers should be supplemented by specifying the implementation of the obligations of the competent authority to regulate legal relations and the terms of their settlement. In this case, the court should be governed by the provisions of the law on the adoption of regulatory documents and their publication. The procedure for the execution of court judgements in cases on challenging regulatory documents consists in publishing information in the official print media about the abolition of a regulatory document [14]. 


\subsection{The content of the powers of the court to make and control a judgement in cases of challenging non-regulatory documents of public authorities}

The exercise of these powers by the court includes: 1) verification of the fulfilment by the public authority of the obligation to inform the court about the restoration of the violated rights of the administrative plaintiff within 1 month (clause 9 of article 227 of the Administrative Court Procedure Code of the Russian Federation); 2) issuance of a writ of execution for compulsory execution of a court judgement in case of failure to comply with the obligation provided for in clause 9 of Article 227 of the Administrative Court Procedure Code of the Russian Federation; 3) the application of measures of responsibility in relation to public law bodies that did not execute the court judgment without good reason.

In French administrative proceedings, a court, in order to ensure the timely execution of its ruling, is empowered to establish an astreinte in relation to officials who have not executed the adopted court decision within the time period established by the court for each day of delay in its execution [15]. Therefore, in order to improve the exercise by the court of its powers to control the execution of the adopted judgement, the court should be empowered to establish astreinte in relation to officials who did not execute the court's judgement within the prescribed period, both in cases of challenging non-regulatory documents and regulatory documents.

\section{Conclusion}

Improving the efficiency of protecting the violated rights of individuals against illegal acts of public authorities should be improved by streamlining the mechanism for exercising the court's powers to make a judgement and monitor its implementation in the following areas: 1) in cases of challenging non-regulatory documents - actions to check the appropriateness of adopted acts; 2) in cases of challenging regulatory documents when they are recognised as invalid - the obligation of the competent authority to regulate legal relations and the terms of their settlement; 3) the application of measures of responsibility in relation to officials who failed to execute the court judgement within the prescribed period - the power to establish astreinte for non-execution of the court judgement.

The research was carried out with the financial support of the Russian Foundation for Basic Research as part of research project No. 19-311-90013

\section{References}

1. Administrative Justice - A Cornerstone of Social Justice in Wales Reform priorities for the Fifth Assembly. Accessed on: August 02, 2021. [Online]. Available: https://gov.wales/sites/default/files/publications/2018-11/administrative-justice.pdf

2. D. Capitant, Geschichte der Verwaltungsgerichtsbarkeit in Frankreich [History of administrative jurisdiction in France], in K.-P. Sommermann, B. Schaffarzik, Handbuch der Geschichte der Verwaltungsgerichtsbarkeit in Deutschland und Europa (Springer-Verlag GmbH Deutschland, ein Teil von Springer Nature, 2019). https://doi.org/10.1007/978-3-642-41235-6_35

3. R. Winkler, Hrvatska Javna Uprava, 7(4), 887-911 (2007)

4. Report of the Chairman of the Supreme Court of the Russian Federation Vyacheslav Lebedev to the meeting of judges of courts of general jurisdiction and commercial courts of the Russian Federation February 09, 2021 [Doklad Predsedatelya 
Verkhovnogo Suda RF Vyacheslava Mikhailovicha Lebedeva k soveshchaniyu sudei sudov obshchei yurisdiktsii i arbitrazhnykh sudov RF 09.02.2021]. Accessed on: August 02, 2021. [Online]. Available: https://vsrf.ru/files/29654/

5. Ch. De Muth, J. Leg. Analysis, 8(1), 121-190 (2016). https://doi.org/10.1093/jla/law003

6. Th. Würtenberger, D. Heckman, Verwaltungsprozessrecht: Ein Studienbuch [Administrative Procedural Law: A Study Book] (Verlag C. H. Beck. München, 2018)

7. W. Heuen, Geschichte des Verwaltungsgerichtsgerechtschützes in den USA [History of Administrative Justice protection in the USA], in K.-P. Sommermann, B. Schaffarzik, Handbuch der Geschichte der Verwaltungsgerichtsbarkeit in Deutschland und Europa (Springer-Verlag GmbH Deutschland, ein Teil von Springer Nature, 2019). https://doi.org/10.1007/978-3-642-41235-6_46

8. R. Brinktrine, Geschichte des Verwaltungsgerichtsgerechtschützes im Vereinigten Königreich von Grossbritanien und Nordirland [History of Administrative Justice in the United Kingdom of Great Britain and Northern Ireland], in K.-P. Sommermann, B. Schaffarzik, Handbuch der Geschichte der Verwaltungsgerichtsbarkeit in Deutschland und Europa (Springer-Verlag GmbH Deutschland, ein Teil von Springer Nature, 2019). https://doi.org/10.1007/978-3-642-41235-6_32

9. G. Gebhardt, Rechtsschutz durch und gegen die Verwaltung in Frankreich-zugleich eine vergleichende Betrachtung zu Annäherungstendenzen des franzosischen und deutschen Verwaltungsrechtsschutzsystems [Legal protection by and against the administration in France-at the same time a comparative view of the convergence tendencies of the French and German administrative legal protection system], in Verwaltungsblätter für Baden-Württemberg, 1-9 (2007)

10. J.S. Oster, German Law J., 9(10), 1267-1297 (2008)

11. A. Bonner, Soviet Justice, 1, 18 (1979)

12. A. Richard, J. Legal Analysis, 8(1), 47-93 (2016). https://doi.org/10.1093/jla/lav012

13. Appeal ruling of the judicial collegium for administrative cases of the Supreme Court of the Russian Federation dated February 26, 2020 No. 45-APA19-36 [Apellyatsionnoe opredelenie sudebnoi kollegii po administrativnym delam Verkhovnogo Suda RF ot 26 fevralya 2020 g. № 45-APA19-36]. Accessed on: August 02, 2021. [Online]. Available: https://legalacts.ru/sud/apelliatsionnoe-opredelenie-sudebnoi-kollegii-po-administrativ nym-delam-verkhovnogo-suda-rossiiskoi-federatsii-ot-26022020-n-45-apa19-36/

14. A.L. Burkov, Sudebnaya zashchita prav grazhdan ot nezakonnykh normativnykh aktov [Judicial protection of the rights of citizens from illegal regulations] (Ekaterinburg: Publishing House of the Ural State University, 2005)

15. A.A. Soloviev, Frantsuzskaya model administrativnoi yustitsii [French model of administrative justice] (Moscow, 2014) 